\title{
GEOCHEMICAL VARIATIONS ON HOSTED VOLCANIC ROCKS OF CIBALIUNG EPITHERMAL GOLD MINERALISATION, BANTEN - INDONESIA: IMPLICATIONS FOR DISTRIBUTION OF SUBDUCTION COMPONENTS
}

\author{
Anastasia Dewi Titisari*1 ${ }^{2}$, David Phillips ${ }^{2}$, and Hartono ${ }^{3}$ \\ ${ }^{1}$ Department of Geological Engineering, Gadjah Mada University \\ ${ }^{2}$ The University of Melbourne, Australia \\ ${ }^{2}$ PT. ANTAM (Persero) Tbk.
}

\begin{abstract}
Subduction of the Indo-Australian Plate beneath the Eurasian Plate formed at least seven magmatic arcs in Indonesia. One of the magmatic arcs is the Neogene Sunda-Banda arc hosts various style of gold mineralisation such as Cibaliung epithermal gold mineralisation. Major and trace element data for host volcanic rocks to the Cibaliung epithermal gold mineralisation is provided by this study to identify the magmatic arc system and the distribution of subduction components. Enriched LILE (Large Ion Lithopile Element) and LREE (Light Rare Earth Element) compositions for basaltic andesite - rhyodacitic samples from the Cibaliung district are characteristic of calc-alkaline arcs. In this typical volcanic arc, the subduction component can be shown to make a dominant contribution to its content of LILE such as Rb, K, Th, and Ba enriched (more than $88 \%$ ) relative to the mantle and within plate inputs. The incompatible elements ( $\mathrm{Hf}, \mathrm{Zr}$, and $\mathrm{Nb}$ ) cannot be observed in the subduction component and thus assumed to be derived from trace element enriched sub-continental lithosphere. These incompatible ele-

${ }^{*}$ Corresponding author: A.D. TITISARI, Department of Geological Engineering, Gadjah Mada University. Jl. Grafika No.2, Bulaksumur, Yogyakarta 55281, Indonesia. E-mail: adtitisari@gmail.com
\end{abstract}

ments are defined as conservative elements therefore it suggests that the magma occurrence is related to a hydrous slab component.

Keywords: Subduction, Indo-Australian plate, magmatic arcs, volcanic rocks, Cibaliung, epithermal gold.

\section{Introduction}

Trace elements and isotope ratios of arc magma in relation to origins of subduction have been subject of several studies. These studies have included investigations into fluid-mobile elements in subduction processes (Leeman, 1996), trace element signature of subduction-zone at 120-180 km depth (Kessel et al. 2005), the geochemical mapping of the arc system and distribution of subduction components (Pearce et al., 2005), and geochemical variations in Chile volcanic zone as the role of fluids in generating arc magmas (Jacques et al., 2014). Another previous study consider that enrichment of LILE such as $\mathrm{Rb}, \mathrm{K}, \mathrm{Ba}$, Th and Sr which is not observed in basalts from oceanic island arcs, is assumed to be subduction-derived associated to active continental margins (Pearce, 1983).

The Cibaliung epithermal gold mineralisation district has also been the subject of several 
geological studies (e.g. Angeles et al., 2002; Harijoko et al., 2004; Harijoko et al., 2007). However, there is limited knowledge in particular geochemical signature of the Cibaliung hosted volcanic rocks associated to typical magmatic arc and magma occurrence at subduction zone. Therefore, investigating the behaviour of major and trace element data for the Cibaliung hosted volcanic rocks is a fundamental data to study the magmatic arc system and to go in better understanding of the subduction processes particularly for distribution of subduction components in relation to the Cibaliung district.

\section{Geological setting}

The Cibaliung epithermal gold mineralisation district is one of the developed gold regions in Western Java, located in the Banten Province, Indonesia, about $150 \mathrm{~km}$ west southwest of Jakarta (Figure 1). The Sunda-Banda magmatic arc is a result of plate convergent between the Indo-Australian Plate and the Eurasian Plate in the Late Miocene (e.g. Soeria-Atmadja et al., 1998) and it is known to host the mineralisation districts. Furthermore, the Sunda-Banda arc is categorized as a continental micro-plate associated with active continental margins (Wilson, 1989). Noticeably, the Cibaliung district which is located within this arc has been affected by processes related to these active continental margins.

The geology of the Cibaliung district has been described by Angeles et al. (2002), Harijoko (2004), and Marjoribanks (2005). The area is dominated by Miocene - Pliocene volcanic rocks belonging to the Honje Igneous Complex (Figure 1). The host volcanic rocks to Cibaliung gold mineralisation are characterized by extensive hydrothermal alteration and abundant quartz veins, and are correlated with the Honje Formation (Figure 2). This formation is composed of a thick sequence of basaltic andesite to andesite lava flows and volcanic breccias, with intercalated tuffaceous sediments (Angeles et al., 2002). The Cibaliung tuff unit is unconformably overlie the Honje Formation, comprises dacitic tuffs that post-date mineralisation (Figure 2). The Citeluk fault zone was identi- fied as a major structure (Figure 2) and the zone is the location of the Cikoneng-Cibitung main mineralisation shoots (Angeles et al., 2002; Marjoribanks, 2005).

\section{Sample selections and analytical tech- niques}

Ten drill core samples and one outcrop sample of andesite (Cbl5WR) were collected from the Cibaliung gold mineralisation district. These samples are representative of the hosted volcanic rocks (Honje Formation). The eleven samples were analysed for major element compositions using XRF spectrometry. Seven of the 11 samples were also analysed for trace element concentrations using ICPMS. The seven samples involve 4 samples of basaltic andesite (AC140-105.15, AC142-106.40, AC143-114.50, and AC143-118.45), two samples of andesite (AC145-104.40 and Cbl5WR), and a sample of rhyodacite (AC139-30.60).

X-Ray fluorescence (XRF) analyses were conducted in the School of Earth Sciences XRF Laboratory, at the University of Melbourne using standard techniques described by Harvey et al. (1996). Analysis of international reference materials indicates that accuracy and precision were within $1-2 \%$. ICP-MS sample preparation and analyses were also performed in the School of Earth Sciences, at the University of Melbourne. The procedures used for these analyses were similar to those described in a previous study (Titisari, 2014).

\section{Results}

\subsection{Cibaliung geochemical element dia- grams}

The Honje Formation volcanic rocks in the Cibaliung district show an overall $\mathrm{SiO}_{2}$ content ranging from 52.84 to $66.36 \mathrm{wt}$. \% (Table 1 and Table 2). $\mathrm{Na}_{2} \mathrm{O}+\mathrm{K}_{2} \mathrm{O}$ contents are $<6 \mathrm{wt} . \%$ in the least altered samples and up to $10.16 \mathrm{wt}$. \% in the altered samples. As the Cibaliung volcanic rock samples were affected by extensive hydrothermal alteration, this study adopted the classification scheme of Winchester and Floyd 


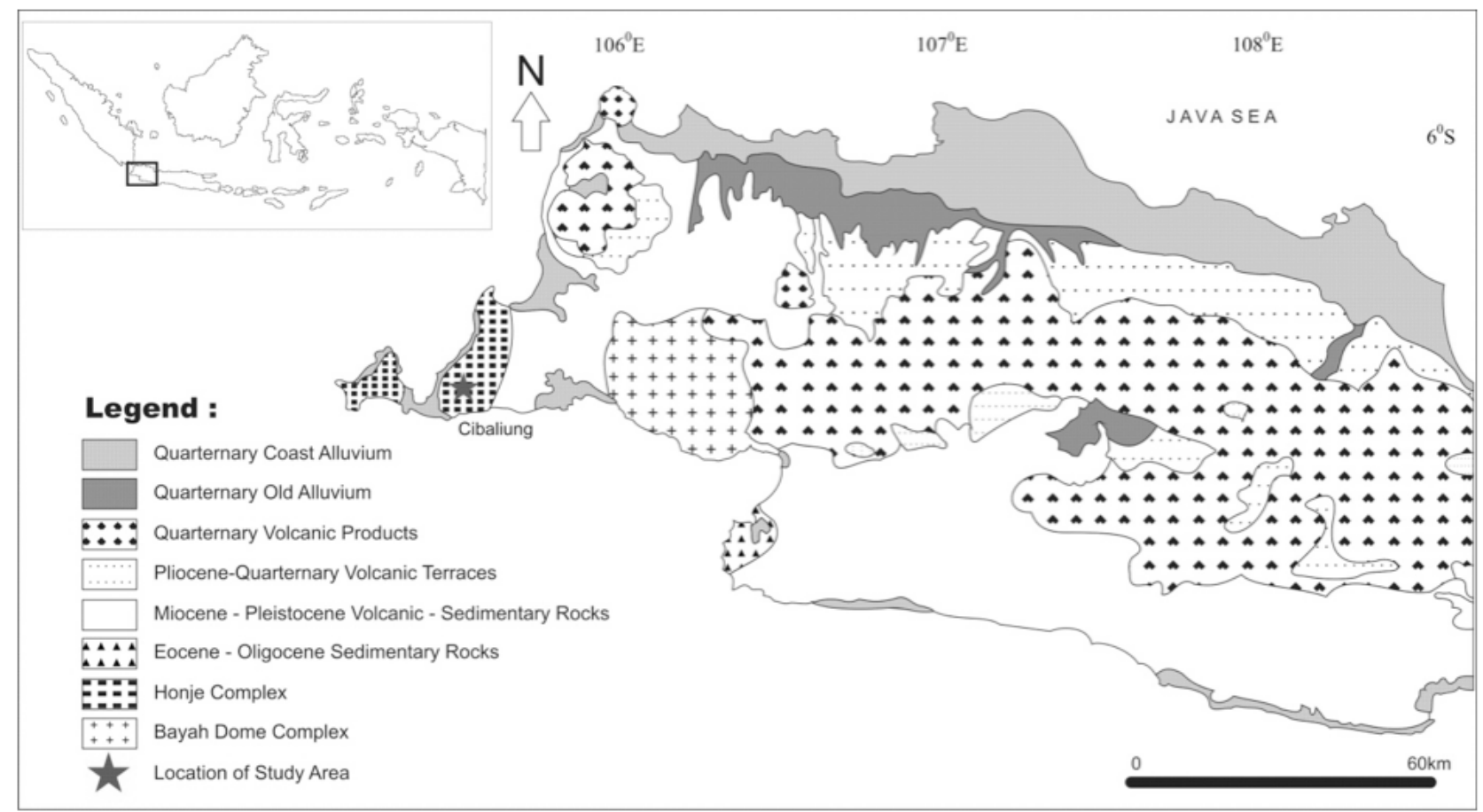

Figure 1: Simplified regional geology map of western Java showing the location of the study area (Modified after Angeles et al., 2002; Budhitrisna 1990, Effendi et al., 1998; Milesi et al., 1994; Milesi et al., 1999; Sudana and Santosa, 1992; Sudjatmiko, 2003; Sujatmiko and Santosa, 1992).

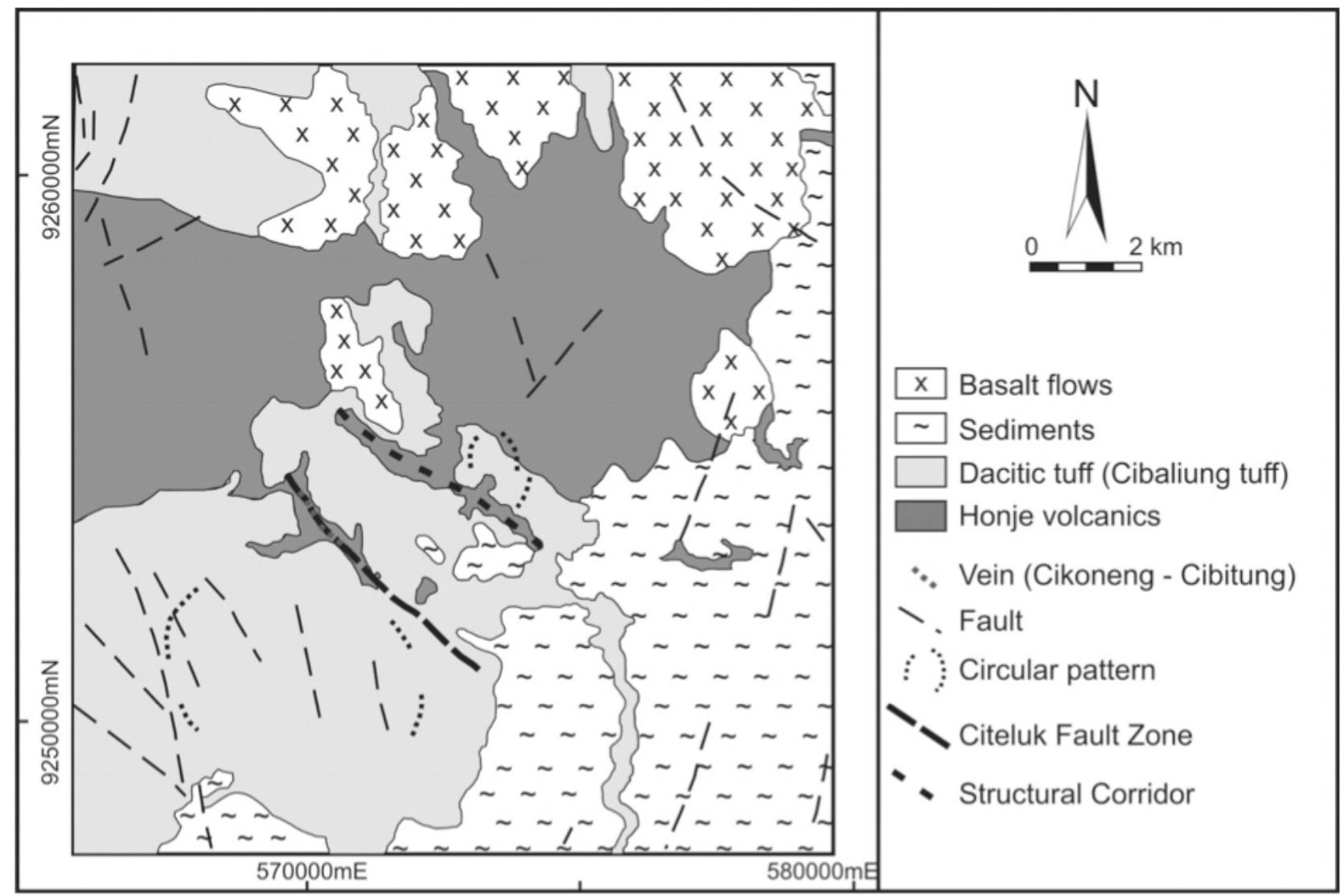

Figure 2: Simplified geological map of the Cibaliung area (modified from Angeles et al., 2002). 
(1977) to classify the rocks. Based on the classification scheme which utilises the $\mathrm{SiO}_{2}$ versus $\mathrm{Nb} / \mathrm{Y}$ plot, the Cibaliung volcanic rocks are classified as basalt, andesites and rhyodacite (Figure 3a).

The $\mathrm{Th} / \mathrm{Yb}$ vs. $\mathrm{Ta} / \mathrm{Yb}$ discrimination diagram, adopted from Pearce (1983) shows the Cibaliung volcanic rocks plotting in a field that define the calc-alkaline arc (Figure 3b). This calc-alkaline suite is characterised by moderate $\mathrm{Th} / \mathrm{Yb}$ ratios $(1.10-1.94)$ and $\mathrm{Ta} / \mathrm{Yb}$ values of 0.09 to 0.07 , relative to the tholeiite and shoshonite magma suites (Figure $3 \mathrm{~b}$ ).

The MORB normalised trace element spider diagram for the Cibaliung volcanic rocks show similar patterns regardless of rock composition (basaltic andesite to rhyodacite) and characterised by positive $\mathrm{Pb}$ and negative Ti anomalies (Figure 4 a). The large ion lithophile (LIL) elements which are also known as low field strength (LFS) elements, such as $\mathrm{Cs}, \mathrm{Rb}, \mathrm{Ba}$, and $\mathrm{K}$ are selectively enriched (Figure $4 \mathrm{a}$ ). The magnitude of this enrichment increases from the basaltic andesite to rhyodacite. The incompatible high field strength (HFS) elements (e.g., P, $\mathrm{Sm}, \mathrm{Y}$ and $\mathrm{Yb}$ ) show variable degrees of enrichment, with Ti being depleted (Figure $4 \mathrm{a}$ ). The patterns of the spider diagrams show typical rocks associated with volcanic arc basalts (e.g. Murphy, 2007). In particular, these patterns are typical of calc-alkaline basalts in active continental margins (e.g. Pearce, 1983; Pearce and Parkinson, 1993).

Chondrite normalised REE patterns for the Cibaliung volcanic rocks (basaltic andesite, andesite and rhyodacite) vary constantly, but all show moderate enrichment in LREE (lightREE) with respect to HREE (heavy-REE) (Figure 4b). The chondrite normalising concentrations are taken from Sun and McDonough (1989). Negative europium (Eu) anomalies are evident in all Cibaliung samples and increases orderly from basic to felsic composition rock (Figure 4b). The chondrite-normalised $\mathrm{La} / \mathrm{Lu}$ ratio of the Cibaliung samples ranges from 0.29 to 0.32 . The REE absolute concentrations are slightly variable, with higher concentrations associated with the succession from basaltic andesite to rhyodacite (Figure $4 \mathrm{p}$ ). The characteristics of
Cibaliung REE patterns (steepened LREE slope followed by flat HREE pattern) are consistent with calc-alkaline arc volcanic rocks.

\subsection{Calculation of subduction components for Cibaliung volcanic rocks}

Trace elements for Cibaliung volcanic rocks can be used to study components input were derived from subduction processes. The contribution of the subduction component can be drawn on the Cibaliung trace element diagram (Figures $5 \mathrm{a}-\mathrm{c}$ ) by adopted to Pearce (1983). Dotted lines which were drawn parallel to MORB and through $\mathrm{Y}$ and $\mathrm{Yb}$ represent the magma composition of Cibaliung volcanic rocks which were derived from a depleted mantle source without elements input from the subduction zone (Figures $5 \mathrm{a}-\mathrm{c}$ ). Dashed lines give the composition of Cibaliung volcanic rocks which were derived from the sub-continental mantle without a subduction component (Figures $5 \mathrm{a}-\mathrm{c}$ ). Therefore, the areas between the dotted and dashed lines (light grey shaded) represent the contribution made by within plate enrichment processes assuming that the original material composition had been MORB mantle source (dark grey shaded). The areas between Cibaliung trace element patterns (solid lines) and dashed lines which shown by white field are then assumed to represent the subduction component (Figures $5 \mathrm{5}-\mathrm{c}$ ).

The calculation of subduction component has been listed on Table 3 to provide the relative contributed components (in \%) from the subduction zone, the depleted mantle and the within plate. The results of the calculation for the basaltic andesite and andesitic rock compositions were obtained from average of normalised concentration for each trace element on the basis of rock compositions as the basaltic andesite and andesitic compositions made up more than one samples.

In general, the calculation (Table 3) shows that enrichment of compatible elements such as $\mathrm{Rb}, \mathrm{K}, \mathrm{Th}$, and $\mathrm{Ba}$ is more than $88 \%$ which is derived from subduction input relative to the mantle and within plate inputs for all of Cibaliung volcanic samples. Moreover, enriched LFS (low field strength) compatible elements of 
Table 1: Whole rock analyses for Cibaliung volcanic rocks (total iron as $\mathrm{Fe}_{2} \mathrm{O}_{3}$, volatile free, normalised to $100 \%$; major elements in weight \%; trace and rare earth elements in ppm; major elements determined by XRF; trace elements by ICPMS

\begin{tabular}{|c|c|c|c|c|c|c|c|}
\hline $\begin{array}{l}\text { Sample } \\
\text { Code }\end{array}$ & AC139-30.6 & $\begin{array}{l}\text { AC140- } \\
105.15\end{array}$ & $\begin{array}{l}\text { AC142- } \\
106.40\end{array}$ & $\begin{array}{l}\text { AC143- } \\
114.50\end{array}$ & $\begin{array}{l}\text { AC143- } \\
118.45\end{array}$ & $\begin{array}{l}\text { AC145- } \\
104.40\end{array}$ & Cbl 5 WR \\
\hline $\begin{array}{l}\text { Sample } \\
\text { Type }\end{array}$ & Drill Core & Drill Core & Drill Core & Drill Core & Drill Core & Drill Core & Outcrop \\
\hline Rock Type & Rhyodacite & $\begin{array}{l}\text { Basaltic } \\
\text { andesite }\end{array}$ & $\begin{array}{l}\text { Basaltic } \\
\text { andesite }\end{array}$ & $\begin{array}{l}\text { Basaltic } \\
\text { andesite }\end{array}$ & $\begin{array}{l}\text { Basaltic } \\
\text { andesite }\end{array}$ & Andesite & Andesite \\
\hline \multicolumn{8}{|c|}{ Major elements (wt \%) } \\
\hline $\mathrm{SiO}_{2}$ & 66.36 & 54.57 & 53.89 & 55.48 & 55.08 & 59.96 & 62.11 \\
\hline $\mathrm{TiO}_{2}$ & 0.84 & 1.14 & 1.26 & 1.32 & 1.23 & 1.16 & 1.14 \\
\hline $\mathrm{Al}_{2} \mathrm{O}_{3}$ & 15.55 & 16.70 & 17.97 & 18.92 & 17.69 & 16.80 & 16.41 \\
\hline $\mathrm{Fe}_{2} \mathrm{O}_{3}$ & 5.90 & 9.44 & 10.27 & 9.23 & 9.91 & 7.89 & 7.78 \\
\hline $\mathrm{MnO}$ & 0.20 & 0.21 & 0.20 & 0.18 & 0.16 & 0.16 & 0.15 \\
\hline $\mathrm{MgO}$ & 2.33 & 5.05 & 4.37 & 3.99 & 3.98 & 2.76 & 2.31 \\
\hline $\mathrm{CaO}$ & 2.84 & 1.47 & 2.13 & 4.01 & 6.06 & 6.41 & 3.80 \\
\hline $\mathrm{Na}_{2} \mathrm{O}$ & 3.18 & 0.54 & 1.40 & 1.97 & 2.50 & 3.70 & 3.63 \\
\hline $\mathrm{K}_{2} \mathrm{O}$ & 2.38 & 9.62 & 7.49 & 4.23 & 2.93 & 0.69 & 1.78 \\
\hline $\mathrm{P}_{2} \mathrm{O}_{5}$ & 0.23 & 0.23 & 0.25 & 0.25 & 0.23 & 0.28 & 0.30 \\
\hline $\mathrm{SO}_{3}$ & 0.05 & 0.83 & 0.53 & 0.22 & 0.04 & 0.03 & 0.41 \\
\hline Total & 99.85 & 99.78 & 99.75 & 99.81 & 99.82 & 99.84 & 99.81 \\
\hline \multicolumn{8}{|c|}{ Trace elements (ppm) } \\
\hline $\mathrm{Ti}$ & 4,716 & 6,705 & 7,205 & 7,345 & 7,021 & 6,393 & 6,592 \\
\hline Co & 8.11 & 24.50 & 23.19 & 22.74 & 24.26 & 13.25 & 14.43 \\
\hline $\mathrm{Rb}$ & 77.2 & 353.8 & 268.5 & 157.7 & 102.5 & 17.2 & 62.6 \\
\hline $\mathrm{Sr}$ & 174 & 211 & 195 & 217 & 274 & 450 & 386 \\
\hline $\mathrm{Y}$ & 38.1 & 26.8 & 31.6 & 26.8 & 26.7 & 36.2 & 40.9 \\
\hline $\mathrm{Zr}$ & 211 & 95 & 103 & 106 & 100 & 150 & 149 \\
\hline $\mathrm{Nb}$ & 5.15 & 3.04 & 3.28 & 3.40 & 3.20 & 4.26 & 4.23 \\
\hline Mo & 0.79 & 0.40 & 0.71 & 0.53 & 0.70 & 1.17 & 0.88 \\
\hline Cs & 2.38 & 2.73 & 5.13 & 8.84 & 2.79 & 5.65 & 1.51 \\
\hline $\mathrm{Ba}$ & 354 & 332 & 673 & 216 & 206 & 95 & 376 \\
\hline $\mathrm{Hf}$ & 5.75 & 2.64 & 2.84 & 2.93 & 2.82 & 4.19 & 4.14 \\
\hline Тa & 0.35 & 0.20 & 0.21 & 0.22 & 0.21 & 0.29 & 0.28 \\
\hline $\mathrm{Pb}$ & 11.45 & 4.13 & 4.49 & 6.54 & 6.01 & 11.47 & 10.18 \\
\hline Th & 7.93 & 3.07 & 3.30 & 3.48 & 3.36 & 5.42 & 5.34 \\
\hline $\mathrm{U}$ & 2.12 & 0.77 & 0.85 & 0.92 & 0.88 & 1.45 & 1.36 \\
\hline \multicolumn{8}{|c|}{ Rare earth elements (ppm) } \\
\hline $\mathrm{La}$ & 17.26 & 10.60 & 12.05 & 11.03 & 10.71 & 14.64 & 16.14 \\
\hline $\mathrm{Ce}$ & 41.53 & 25.85 & 28.67 & 29.38 & 26.53 & 36.03 & 38.41 \\
\hline $\operatorname{Pr}$ & 5.46 & 0.41 & 3.81 & 3.69 & 3.54 & 4.77 & 5.09 \\
\hline $\mathrm{Nd}$ & 23.50 & 15.32 & 17.16 & 16.55 & 15.91 & 21.10 & 22.70 \\
\hline Sm & 5.87 & 4.04 & 4.42 & 4.36 & 4.16 & 5.47 & 5.82 \\
\hline $\mathrm{Eu}$ & 1.41 & 1.24 & 1.42 & 1.33 & 1.30 & 1.52 & 1.64 \\
\hline Gd & 6.29 & 4.52 & 5.07 & 4.81 & 4.62 & 6.04 & 6.64 \\
\hline $\mathrm{Tb}$ & 1.03 & 0.73 & 0.82 & 0.78 & 0.75 & 0.99 & 1.06 \\
\hline Dy & 6.52 & 4.64 & 5.16 & 4.93 & 4.79 & 6.21 & 6.71 \\
\hline Ho & 1.43 & 1.02 & 1.13 & 1.06 & 1.04 & 1.36 & 1.47 \\
\hline Er & 4.10 & 2.89 & 3.19 & 3.00 & 2.95 & 3.86 & 4.18 \\
\hline $\mathrm{Tm}$ & 0.629 & 0.434 & 0.476 & 0.446 & 0.442 & 0.589 & 0.626 \\
\hline $\mathrm{Yb}$ & 4.10 & 2.80 & 3.01 & 2.87 & 2.87 & 3.81 & 3.96 \\
\hline $\mathrm{Lu}$ & 0.614 & 0.420 & 0.454 & 0.422 & 0.426 & 0.573 & 0.601 \\
\hline
\end{tabular}


Table 2: Whole rock analyses for Cibaliung volcanic rocks (total iron as $\mathrm{Fe}_{2} \mathrm{O}_{3}$, volatile free, normalised to $100 \%$; major elements in weight \%; trace and rare earth elements in ppm; major and trace elements determined by XRF).

\begin{tabular}{|c|c|c|c|c|}
\hline Sample Code & AC139-99.55 & AC142-102.60 & AC142-102.80 & AC145-101.05 \\
\hline Sample Type & Drill Core & Drill Core & Drill Core & Drill Core \\
\hline Rock Type & $\begin{array}{l}\text { Basaltic } \\
\text { andesite }\end{array}$ & Basaltic andesite & $\begin{array}{l}\text { Basaltic } \\
\text { andesite }\end{array}$ & Andesite \\
\hline \multicolumn{5}{|c|}{ Major elements (wt \%) } \\
\hline $\mathrm{SiO}_{2}$ & 54.17 & 52.84 & 53.45 & 61.13 \\
\hline $\mathrm{TiO}_{2}$ & 1.23 & 1.27 & 1.26 & 1.15 \\
\hline $\mathrm{Al}_{2} \mathrm{O}_{3}$ & 17.26 & 18.19 & 17.81 & 16.98 \\
\hline $\mathrm{Fe}_{2} \mathrm{O}_{3}$ & 9.78 & 10.65 & 10.58 & 7.72 \\
\hline $\mathrm{MnO}$ & 0.21 & 0.20 & 0.20 & 0.12 \\
\hline $\mathrm{MgO}$ & 4.69 & 4.43 & 4.45 & 2.34 \\
\hline $\mathrm{CaO}$ & 1.94 & 2.47 & 2.26 & 5.87 \\
\hline $\mathrm{Na}_{2} \mathrm{O}$ & 0.54 & 1.45 & 1.48 & 3.64 \\
\hline $\mathrm{K}_{2} \mathrm{O}$ & 8.90 & 7.82 & 7.54 & 0.54 \\
\hline $\mathrm{P}_{2} \mathrm{O}_{5}$ & 0.26 & 0.27 & 0.26 & 0.29 \\
\hline $\mathrm{SO}_{3}$ & 0.76 & 0.21 & 0.49 & 0.08 \\
\hline Total & 99.74 & 99.80 & 99.78 & 99.86 \\
\hline \multicolumn{5}{|c|}{ Trace elements (ppm) } \\
\hline V & 276 & 312 & 295 & 128 \\
\hline $\mathrm{Cr}$ & 40.9 & 36.2 & 38.2 & 18.4 \\
\hline $\mathrm{Ni}$ & 31.7 & 29.3 & 33.5 & 12.1 \\
\hline $\mathrm{Cu}$ & 84.6 & 84.5 & 86.7 & 41.6 \\
\hline $\mathrm{Zn}$ & 94 & 113 & 103 & 96 \\
\hline $\mathrm{Ga}$ & 16.30 & 13.50 & 17.90 & 18.90 \\
\hline As & 48.80 & 37.80 & 38.70 & 25.30 \\
\hline $\mathrm{Rb}$ & 314.8 & 285.3 & 279.4 & 14.7 \\
\hline $\mathrm{Sr}$ & 389 & 200 & 206 & 422 \\
\hline Y & 27.8 & 25.4 & 27.5 & 40.8 \\
\hline $\mathrm{Zr}$ & 104 & 109 & 113 & 153 \\
\hline $\mathrm{Nb}$ & 9.20 & 10.30 & 9.90 & 10.30 \\
\hline Mo & 5.50 & 5.38 & 6.10 & 7.50 \\
\hline $\mathrm{Ba}$ & 679 & 398 & 526 & 60 \\
\hline
\end{tabular}



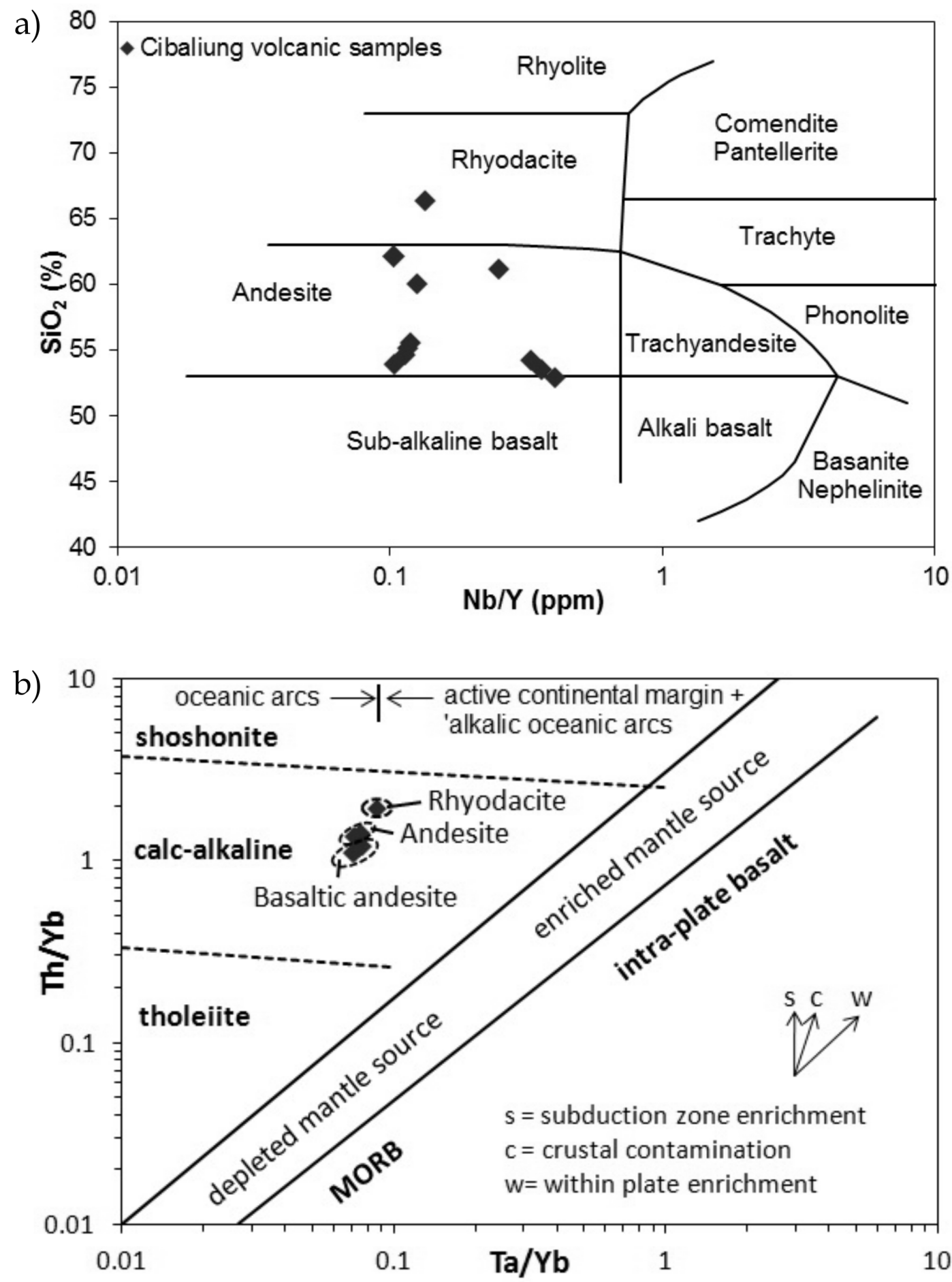

Figure 3: a) Composition of Cibaliung volcanic rocks plotted on the Winchester and Floyd (1977) classification scheme, showing compositions from basalts to rhyodacites. b) Th/Yb vs. Ta/Yb diagram showing the Pearce (1983) discrimination scheme, with Cibaliung volcanic rocks plotting in the calc-alkaline arc fields. 

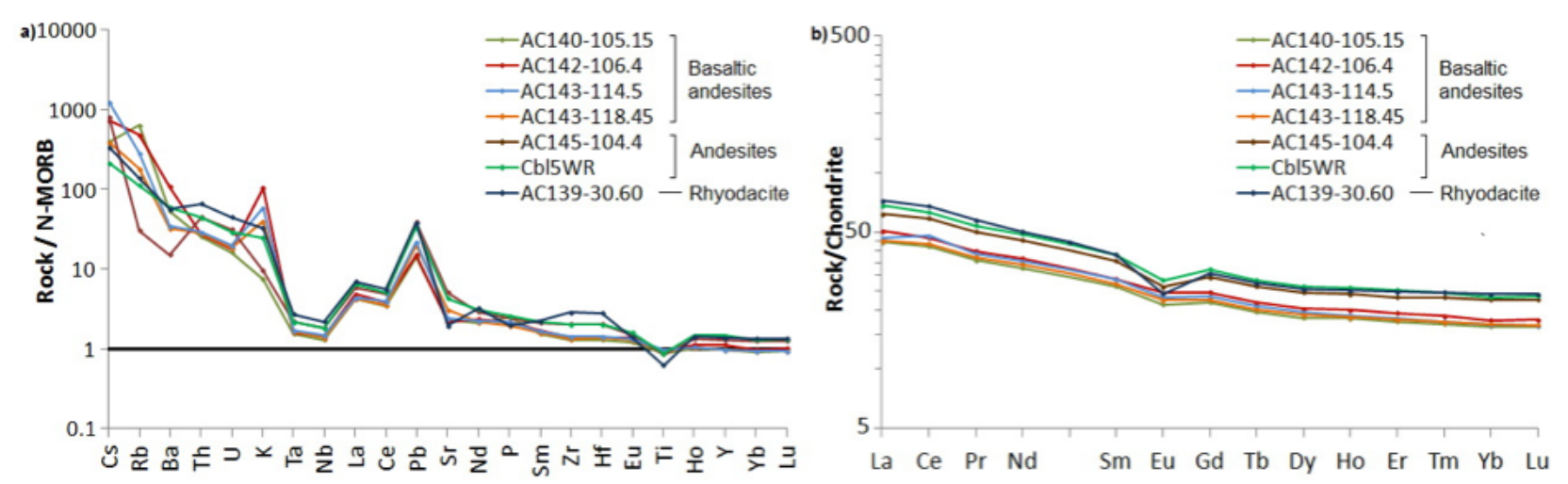

Figure 4: a) MORB normalised trace element spider diagrams for the Cibaliung volcanic rocks, showing patterns typical of calc-alkaline arcs associated with active continental margins; $b$ ) Chondrite-normalised rare-earth-element (REE) plots for the Cibaliung volcanic rocks. The elevated light-REE concentration profiles are typical of calc-alkaline arc volcanic rocks. Note: MORB normalising factors and chondrite normalisation concentrations are from Sun and McDonough (1989).

Table 3: Contributed components of the source region for the Cibaliung volcanic rocks from the subduction zone, depleted mantle, and the within plate.

\begin{tabular}{|c|c|c|c|c|c|c|c|c|c|}
\hline Rock & \multicolumn{3}{|c|}{ Basaltic Andesite } & \multicolumn{3}{|c|}{ Andesite } & \multicolumn{3}{|c|}{ Rhyodacite } \\
\hline Samples & $\begin{array}{l}\text { AC140-10 } \\
106.40 ; A \\
\text { AC143-11 }\end{array}$ & $\begin{array}{l}15 ; \mathrm{AC} 1 \\
43-114.5 \\
45\end{array}$ & & $\begin{array}{l}\text { AC145-10 } \\
\text { Cbl5WR }\end{array}$ & & & AC139-30 & & \\
\hline $\begin{array}{l}\text { Contributed } \\
\text { component }\end{array}$ & $\begin{array}{c}\text { Subduction } \\
(\%)\end{array}$ & $\begin{array}{c}\text { Mantle } \\
(\%)\end{array}$ & $\begin{array}{c}\text { Within } \\
\text { Plate } \\
(\%) \\
\end{array}$ & $\begin{array}{l}\text { Subduction } \\
(\%)\end{array}$ & $\begin{array}{c}\text { Mantle } \\
(\%)\end{array}$ & $\begin{array}{l}\text { Within } \\
\text { Plate } \\
(\%) \\
\end{array}$ & $\begin{array}{c}\text { Subduction } \\
(\%)\end{array}$ & $\begin{array}{c}\text { Mantle } \\
(\%)\end{array}$ & $\begin{array}{l}\text { Within } \\
\text { Plate } \\
(\%)\end{array}$ \\
\hline $\mathrm{Rb}$ & 98.96 & 0.78 & 0.26 & 92.98 & 5.85 & 1.17 & 95.55 & 3.15 & 1.31 \\
\hline K & 97.43 & 2.12 & 0.45 & 83.70 & 14.03 & 2.28 & 90.58 & 7.63 & 1.79 \\
\hline Th & 94.84 & 3.96 & 1.20 & 94.79 & 4.42 & 0.79 & 95.66 & 3.09 & 1.25 \\
\hline $\mathrm{Ba}$ & 93.57 & 4.89 & 1.54 & 88.10 & 10.01 & 1.89 & 90.28 & 6.90 & 2.82 \\
\hline $\mathrm{Ce}$ & 64.16 & 32.25 & 3.59 & 60.00 & 32.84 & 7.16 & 57.55 & 29.85 & 12.60 \\
\hline $\mathrm{Sr}$ & 50.11 & 45.46 & 4.43 & 63.11 & 32.84 & 4.05 & 12.64 & 82.97 & 4.40 \\
\hline $\mathrm{P}$ & 47.23 & 44.22 & 8.55 & 34.74 & 51.00 & 14.26 & 0.00 & 64.93 & 35.07 \\
\hline $\mathrm{Sm}$ & 22.50 & 67.37 & 10.13 & 26.87 & 73.08 & 0.76 & 16.95 & 70.80 & 12.25 \\
\hline $\mathrm{Ta}$ & 16.29 & 64.85 & 18.85 & 11.88 & 75.53 & 12.59 & 12.55 & 62.57 & 24.88 \\
\hline $\mathrm{Hf}$ & - & 74.64 & 25.36 & - & 72.25 & 27.75 & - & 52.39 & 47.61 \\
\hline $\mathrm{Zr}$ & - & 78.35 & 21.65 & - & 74.63 & 25.37 & - & 53.30 & 46.70 \\
\hline $\mathrm{Nb}$ & - & 100.00 & - & - & 99.73 & 3.92 & - & 83.87 & 16.13 \\
\hline $\mathrm{Ti}$ & - & 100.00 & - & - & 100.00 & - & - & 100.00 & - \\
\hline Y & - & 100.00 & - & - & 100.00 & - & - & 100.00 & - \\
\hline $\mathrm{Yb}$ & - & 100.00 & - & - & 100.00 & - & - & 100.00 & - \\
\hline
\end{tabular}



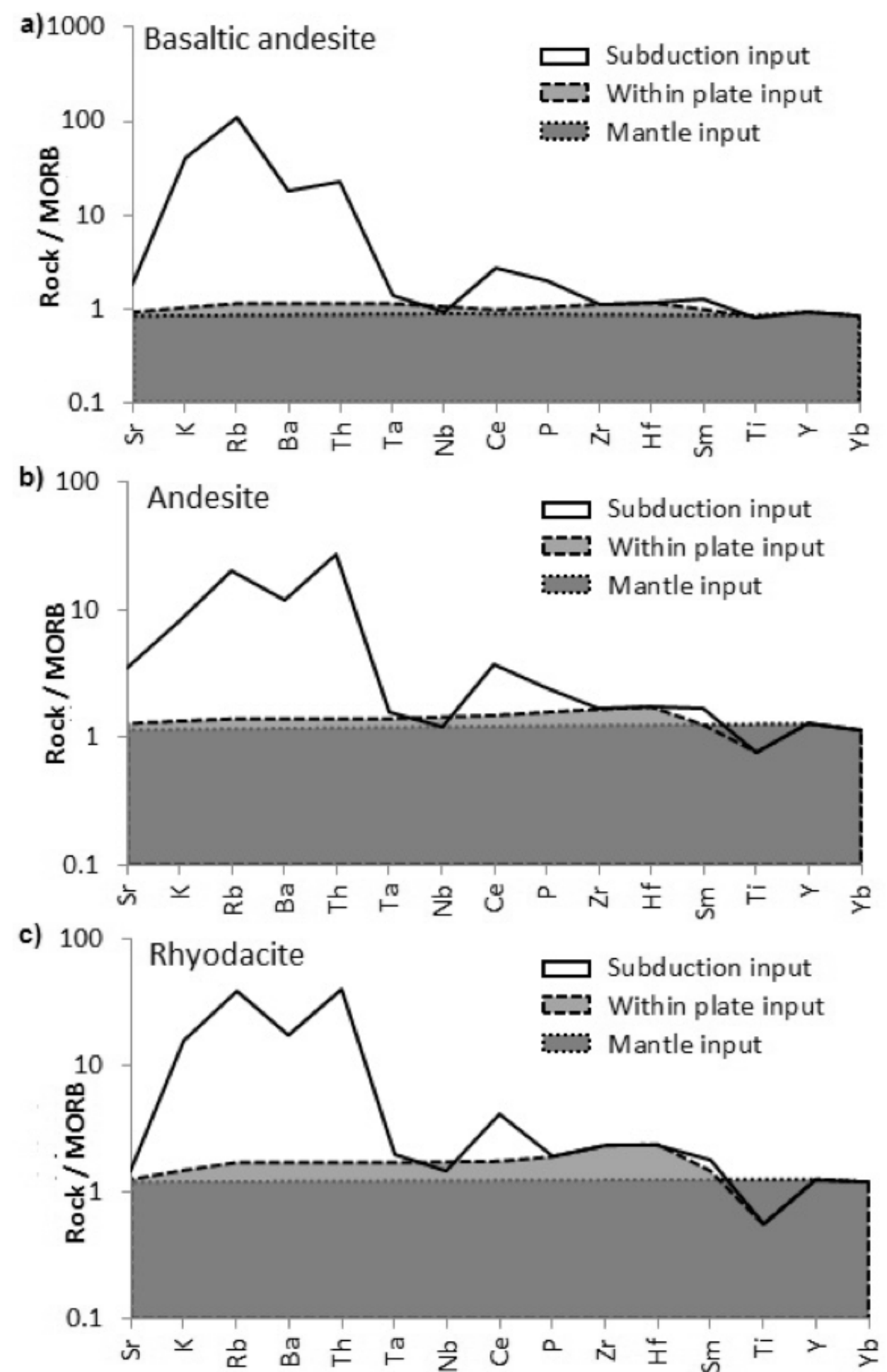

Figure 5: a-c) Geochemical patterns for Cibaliung volcanic rocks showing contribution of component source from the subduction input, from within plate and from mantle (in percentage), adopted from Pearce (1983). The MORB normalizing factors are referred from Pearce (1983). Note: Dotted line represents original magma composition which was derived from depleted MORB mantle source (dark grey shaded). Dashed line represents an elemental enrichment controlled by within plate processes (light grey shaded). Solid line represents contribution of subduction zone (white field). 
$\mathrm{Rb}, \mathrm{K}$, and $\mathrm{Ba}$ from subduction component for basaltic andesite are the greatest with respect to more felsic rocks (Table 3). In contrast, contribution of incompatible elements such as $\mathrm{Hf}, \mathrm{Zr}$, and $\mathrm{Nb}$, from subduction input is not observed for all of the volcanic samples. Distribution of these HFS (high field strength) elements from mantle component is greater with the succession from felsic to basic rock compositions (Table 3). While enrichment of $\mathrm{Ba}, \mathrm{Ce}, \mathrm{P}, \mathrm{Sm}, \mathrm{Hf}$, $\mathrm{Zr}$, and $\mathrm{Nb}$ which are from within plate component, are higher in felsic rock with respect to more basic rocks.

To classify non-conservative and conservative elements of the Cibaliung volcanic rocks from subduction input, this study adopted the classification scheme of Pearce and Peate (1995) which utilises the percentage of subduction input versus the LFS and HFS elements. With regards to the calculation in Table 3, a diagram of subduction input of non-conservative and conservative elements for the Cibaliung volcanic samples are shown on Figure 6. The diagram shows that compatible elements of $\mathrm{Rb}$, $\mathrm{K}$, Th, and Ba which are more than $80 \%$ of subduction input (\% SZ) are classified highly non-conservative elements for all rock types of samples. Ce element with 57.55-64.16\% of subduction input is characteristic of moderately non-conservative elements. Elements of Sr and P (ranging 12.64-63.11\% and 0-47.23\% of subduction input, respectively) are scattered as moderately non-conservative and conservative elements. Sm element of all samples which has various from 16.95 to $26.87 \%$ of subduction component is categorised slightly nonconservative elements. In contrast, the incompatible HSFEs of $\mathrm{Ta}, \mathrm{Hf}, \mathrm{Zr}, \mathrm{Nb}, \mathrm{Ti}, \mathrm{Y}$, and $\mathrm{Yb}$ ( $<17 \%$ of subduction input) that were derived from a depleted MORB mantle source are determined as conservative elements.

\section{Discussions}

Tectono-magmatic diagram of Cibaliung trace elements on classification scheme of Pearce (1983) using HFS (high field strength) incompatible element ratios of $\mathrm{Ta} / \mathrm{Yb}$ vs $\mathrm{Th} / \mathrm{Yb}$ shows that Cibaliung district characterises a calc-alkalin arc in active continental margin which is characterised by moderate $\mathrm{Th} / \mathrm{Yb}$ ratios and $\mathrm{Ta} / \mathrm{Yb}$ values, relative to the tholeiite and shoshonite magma suites (Figure $3 \mathrm{~b}$ ). The spider diagram of Cibaliung trace elements showing enrichment of LILE (Large Ionic Lithophile Elements) composition is a typical calc-alkalin arc in active continental margin (Figure 4a) and related intimately to subduction input (Figures $5 \mathrm{a}-\mathrm{c}$ ). Similarly, chondrite-normalised patterns of Cibaliung REEs which exhibit enrichment of LREE (Light Rare Earth Elements) concentration is characteristic of calc-alkalic arc (Figure $4 \mathrm{~b}$ ).

According to Soeria-Atmaja (2005), SundaBanda Arc consists of island-arc tholeiitic lava flows in the Early Tertiary, tholeiitic basalt in the beginning of the Late Tertiary succeeded by medium-K calc-alkaline magmatism, and calcalkaline magmatism in the Pliocene and Quaternary. This statement is likely conforming to the type of magmatism and tectonic setting in Cibaliung district scale which is located on the Sunda-Banda Arc. Setijadji et al. (2006) who classified Upper Miocene Javan igneous rocks as medium-K calc-alkaline affinity has strongly supported the assumption of this current study.

On the basis of the calculation and diagram of component source for Cibaling volcanic rocks in the subduction zone (Table and Figures $5 \mathrm{a}-$ c), it is clear that input of the source components has played an important role on occurrence of Cibaliung volcanic arc. The phenomena show that the magma source of Cibaliung eruptions have been contributed dominantly by input of subduction. This contribution presented by compatible element of $\mathrm{Rb}, \mathrm{K}$, Th and $\mathrm{Ba}$ is the greatest of source components (more than $88 \%$ ) relatives to the mantle and within plate components for all of volcanic rock samples (Table 3). These compatible elements are classified highly non-conservative elements as they are more than $80 \%$ of subduction input (\%SZ) (Figure 6). This dominated subduction input is also illustrated as the widest area of the source component fields on the white domain of the diagrams for basaltic andesite, andesite, and rhyodacite (Figures $5 \mathrm{a}-\mathrm{c}$ ). Other less white domains are shown by contribution 


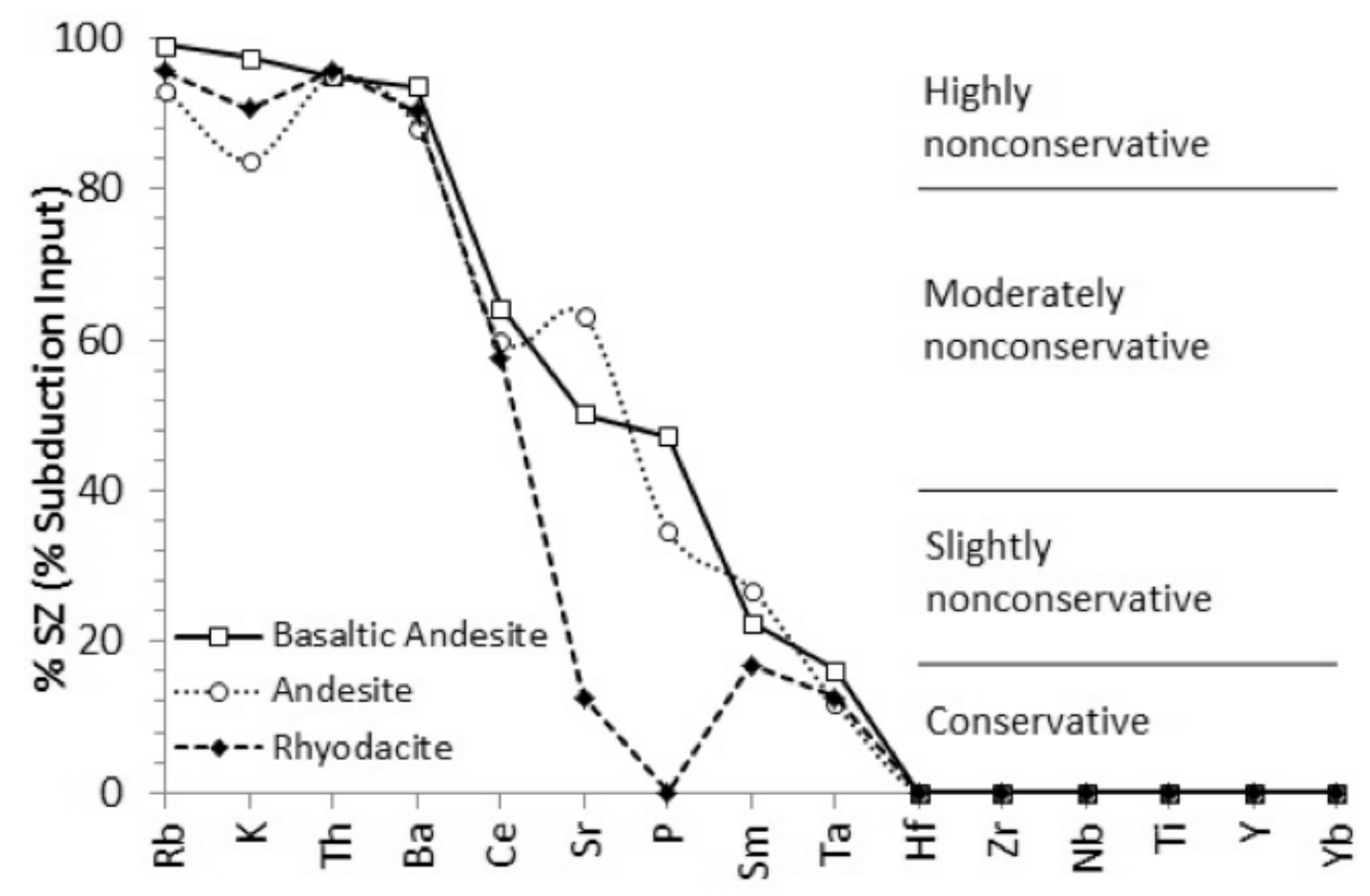

Figure 6: Concluded subduction zone contribution for non-conservative elements (as \% SZ) to the mantle source of Cibaliung erupsions, adopted from Pearce and Peate (1995).

of Ce, $\mathrm{P}$ and Sm elements from subduction input (Figures $5 \mathrm{a}-\mathrm{c}$ ) which are characteristics of moderately non-conservative - conservative elements (Figure 6). On the other hand, contribution of incompatible elements such as $\mathrm{Hf}$, $\mathrm{Zr}$, and $\mathrm{Nb}$ from subduction input cannot be noticed for all type of rock samples, suggesting that these elements were derived from trace element enriched sub-continental lithosphere. Consistency of the results support arguments that magma occurrence of the Cibaliung eruptions were contributed dominantly by subduction input.

Within plate component also contributed significantly on the Cibaliung volcanism which produced mostly basaltic andesite, andesitic and ryodacitic rocks comprised the Honje Formation host rocks. Trace elements such as $\mathrm{Ba}, \mathrm{Ce}, \mathrm{P}, \mathrm{Sm}, \mathrm{Hf}, \mathrm{Zr}$ and $\mathrm{Nb}$ enriched subcontinental mantle are greater in felsic rock with respect to more basic rocks. This contribution made by within plate is indicated by the larger field (shown by light grey shaded area on Figure 5c) for the more felsic rock.

Many authors (e.g. Woodhead, 1989; Car- roll and Wyllie, 1990; Kelley and Cottrell, 2009; Zimmer et al., 2010; Kelley et al. 2012) generally agreed that water plays a major role in producing calc-alkalic magmas and so water is one of the most sensitive indicators of the presence of subduction components in volcanic arc magmas. Element behaviour of ionic radius and mantle-melt bulk distribution coefficient in relation to subduction system has also been subject of an experiment study (Pearce and Peate, 1995). According this study, the ionic radius could be an indicator of partitioning into aqueous fluids. Pearce and Peate (1995) suggested that when HFS incompatible elements of $\mathrm{Nb}$ and $\mathrm{Zr}$ in magma fluids behave nonconservative elements, reflecting the magma is related to a siliceous melt slab component (Figure 7 a). However, if these elements which are typically insoluble in $\mathrm{H}_{2} \mathrm{O}$-rich solutions (Murphy, 2007) perform conservative elements, indicating the magma is related to a hydrous slab component (Figure 7b). The latter phenomenon is showed by the Cibaliung diagram of distribution for non-conservative and conservative elements (Figure 6). Consequently, it can be 
suggested that the magmas of Cibaliung calcalkaline volcanic arc are associated with the hydrous slab component within the subduction zone.

Previous studies (e.g. Manning, 2004; Hermann et al., 2006; Zheng et al., 2011) present that hydrous melts play a principal role in mobilizing water-insoluble incompatible elements such as light rare earth elements (LREE) from the subducting rocks. Another study presented that enriched large ion lithophile elements (LILE) and light rare earth elements (LREE) relative to the primitive mantle is attributing to slab dehydration and element transport at mantle depths of 80 to $130 \mathrm{~km}$ (e.g. Zheng and Hermann, 2014). Therefore, the current study suggest that enrichment of large ion lithophile elements (LILE) and light rare earth elements (LREE) compositions for the Cibaliung volcanic rocks indicates the important role of the subduction process associated with the hydrous slab component in transporting the elements on the Cibaliung volcanism.

\section{Conclusions}

The basaltic andesite - rhyodacite samples in the Cibaliung epithermal gold mineralisation district are characterised by enriched LILE and LREE, signatures typical of calc-alkaline arcs. In this typical volcanic arc, compatible elements of $\mathrm{Rb}, \mathrm{K}, \mathrm{Th}, \mathrm{Ba}$ enriched are assumed to be subduction-derived, more than $88 \%$, indicates that the magma source of the Cibaliung eruptions have been contributed dominantly by subduction input relative to the mantle and within plate inputs. The incompatible elements of Hf, $\mathrm{Zr}$ and $\mathrm{Nb}$ for the Cibaliung hosted volcanic rocks are assumed to be derived from trace element enriched sub-continental lithosphere as these elements cannot be noticed in subduction components. These elements perform the conservative elements, suggesting a strong relationship between the magma occurrence and a hydrous slab component in the subduction system.

\section{Acknowledgments}

The authors wish to acknowledge the management of PT. ANTAM (Persero) Tbk. for permission to publish this paper. We are thankful to Prof. Jon Woodhead and Dr. Allan Greig for their contributions to the geochemical (major and trace element) analyses. We also thank Directorate General of Higher Education (DGHE) of the Indonesia Government and the University of Melbourne, Australia for financial supports.

\section{References}

Angeles, C. A., Prihatmoko, S. and Walker, J. S. (2002) 'Geology and Alteration-Mineralization Characteristics of the Cibaliung Epithermal Gold Deposit, Banten, Indonesia', Resource Geology, 52(4), 329-339.

Budhitrisna, T. (1990) Geological Map of the Tasikmalaya, Jawa Barat, sheet 1, 1:100.000, Bandung: Geological Research and Development Centre, (Scale 1:100.000).

Carroll, M. R. and Wyllie, P. J. (1990) 'The system tonalite- $\mathrm{H}_{2} \mathrm{O}$ at $15 \mathrm{kbar}$ and the genesis of calc-alkaline magmas', American Mineralogist, 75, 345-357.

Effendi, A. C., Kusnama and Hermanto, B. (1998) Geological Map of the Bogor Quadrangle, Jawa, sheet 1, 1:100.000, Scale 1:100.000, Bandung: The Geological Research and Development Centre.

Harijoko, A. (2004) Ore Genesis of The Cibaliung Epithermal Gold Deposit in Western Java, Indonesia, unpublished thesis Kyushu University], unpublished.

Harijoko, A., Ohbuchi, Y., Motomura, Y., Imai, A. and Watanabe, K. (2007) 'Characteristics of the Cibaliung Gold Deposit: Miocene LowSulfidation-Type Epithermal Gold Deposit in Western Java, Indonesia', Resource Geology, 57(2), 114-123.

Harijoko, A., Sanematsu, K., Duncan, R. A., Prihatmoko, S. and Watanabe, K. (2004) 'Timing of the Mineralization and Volcanism at Cibaliung Gold Deposit, Western Java - Indonesia', Resource Geology, 54(2), 187-195.

Harvey, P. K., Lovell, M. A., Brewer, T. S., Locke, J. and Mansley, E. (1996) 'Measurement of thermal neutron absorption cross section in selected geochemical reference materials', Geostandards Newsletter, 20, 79-85.

Hermann, J., Spandler, C., Hack, A. and Korsakov, A. V. (2006) 'Aqueous fluids and hydrous melts 

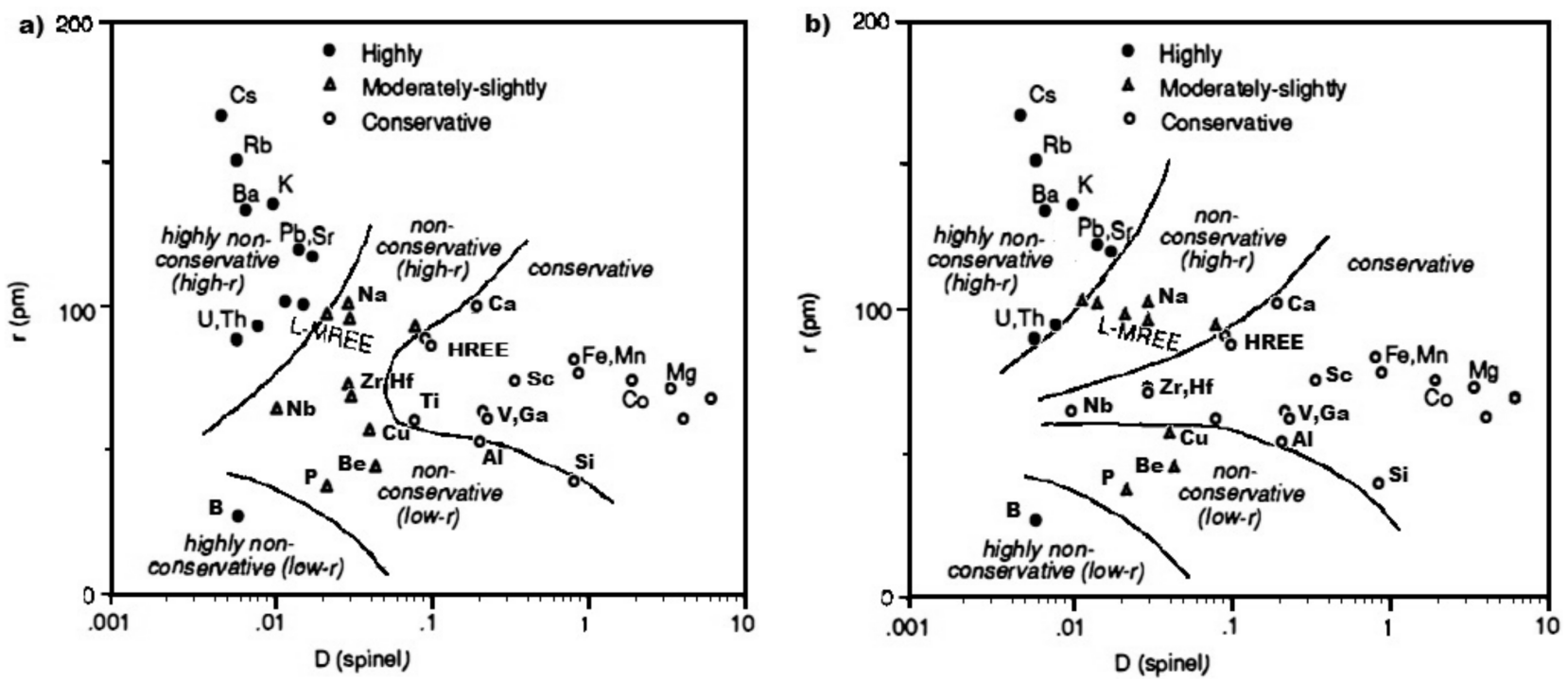

Figure 7: Behavior of elements in the subduction system as a function of ionic radius (r) and bulk mantle melt distribution coefficient (D) for a) siliceous melts and b) hydrous fluids (After Pearce and Peate, 1995).

in high-pressure and ultra-high pressure rocks: Implications for element transfer in subduction zones', Lithos, 92, 399-417.

Jacques, G., Hoernle, K., Gill, J., Wehrmann, H., Bindeman, I. and Lara, L. E. (2014) 'Geochemical variations in the Central Southern Volcanic Zone, Chile (38-430S): The role of fluids in generating arc magmas', Chemical Geology, 371, 27-45.

Kelley, K. A. and Cottrell, E. (2009) 'Water and Oxidation State of Subduction Zone Magmas', Science, 325, 605-607.

Kelley, K. A., Plank, T., Newman, S., Stolper, E. M., Grove, T. L., Parman, S. and Hauri, E. H. (2012) 'Mantle Melting as a Function of Water Content beneath the Mariana Arc', Journal of Petrology, 51(8), 1711-1738.

Kessel, R., Schmidt, M. W., Ulmer, P. and Pettke, T. (2005) 'Trace element signature of subductionzone fluids, melts and supercritical liquids at 120 $180 \mathrm{~km}$ depth', Nature, 437, 724-727.

Leeman, W. P. (1996) 'Boron and Other Fluid-mobile Elements in Volcanic Arc Lavas: Implications for Subduction Processes', Geophysical Monograph Series, 96, 269-276.

Manning, C. E. (2004) 'The chemistry of subductionzone fluids', Earth and Planetary Science Letters, 223, 1-16.

Marjoribanks, R. (2005) Geology and Structural Controls on Gold Mineralisation in The Cibaliung Project Area, Banten Province, Indonesia, Perth: A Report compiled for PT Cibaliung Sumberdaya.
Milesi, J. P., Marcoux, E. and Nehlig (1994) 'Cirotan, West Java, Indonesia: A 1.7 Ma Hybrid Epithermal Au-Ag-Sn-W Deposit', Economic Geology, 89(2), 227-245.

Milesi, J. P., Marcoux, E., Sitorus, T., Simandjuntak, M., Leroy, J. and Baily, L. (1999) 'Pongkor (West Java, Indonesia): a Pliocene supergeneenriched epithermal Au-Ag-(Mn) deposit', Mineralium Deposita, 34, 131-149.

Murphy, J. B. (2007) 'Arc Magmatism II: Geochemical and Isotopic Characteristics', Geoscience Canada, 34(1), 7-35.

Pearce, J. A. (1983) 'Role of the Sub-continental Lithosphere in Magma Genesis at Active Continental Margins' in Hawkesworth, C. J. and Norry, M. J., eds., Continental Basalts and Mantle Xenolith, Cheshire: Shiva Publishing Limited, 230-249.

Pearce, J. A. and Parkinson, I. J. (1993) 'Trace element models for mantle melting: application to volcanic arc petrogenesis' in Prichard, H. M., Alabaster, T., Harris, N. B. W. and C.R., N., eds., Magmatic Processes and Plate Tectonics, Geological Society Special Publication, 373-403.

Pearce, J. A. and Peate, D. W. (1995) 'Tectonic Implications of the Composition of Volcanic Arc Magmas', Annual Review of Earth and Planetary Sciences, 23, 251-185.

Pearce, J. A., Stern, R. J., Bloomer, S. H. and Fryer, P. (2005) 'Geochemical mapping of the Mariana arcbasin system: Implications for the nature and distribution of subduction components', Geochemistry Geophysics Geosystems, 6(7). 
Setijadji, L. D., Kajino, S., Imai, A. and Watanabe, K. (2006) 'Cenozoic Island Arc Magmatism in Java Island (Sunda Arc, Indonesia): Clues on Relationships between Geodynamics of Volcanic Centers and Ore Mineralization', Resource Geology, 56(3), 267-292.

Soeria-Atmadja, R. and Noeradi, D. (2005) 'Distribution of Early Tertiary volcanic rocks in south Sumatra and west Java', The Island Arc, 14, 679686.

Soeria-Atmadja, R., Suparka, S., Abdullah, C., Noeradi, D. and Sutanto (1998) 'Magmatism in western Indonesia, the trapping of the Sumba Block and the gateways to the east of Sundaland', Journal of Asian Earth Sciences, 16(1), 1-12.

Sudana, D. and Santosa, S. (1992) Geological Map of the Cikarang Quadrangle, Jawa, sheet 1:100.000, Scale 1: 100.000, Bandung: Geological Research and Development Centre.

Sudjatmiko (2003) Geological Map of the Cianjur Quadrangle, Jawa, sheet Cianjur 9/XIII-E, 1:100.000, Bandung: Geological Research and Development Centre, (Scale 1:100.000).

Sujatmiko and Santosa, S. (1992) Geological Map of the Leuwidamar Quadrangle, Jawa, sheet 1:100.000, Bandung: Geological Research and Development Centre, (Scale 1:100.000).

Sun, S. S. and McDonough, W. F. (1989) 'Chemical and isotopic systematics of oceanic basalts: implications for mantle composition and processes',
Geological Society Special Publication, 42, 313345.

Titisari, A. D. (2014) Geochronology and geochemistry of Cenozoic volcanism in relation to epithermal gold mineralisation in western Java, Indonesia. Thesis (PhD), unpublished thesis The University of Melbourne, Australia, $297 \mathrm{p}$.

Wilson, M. (1989) Igneous Petrogenesis, London: Unwin Hyman Ltd. Winchester, J. A. and Floyd, P. A. (1977) 'Geochemical discrimination of different magma series and their differentiation products using immobile elements', Chemical Geology, 20, 325-343.

Woodhead, J. D. (1989) 'Geochemistry of the Mariana arc (western Pacific): Source composition and processes', Chemical Geology, 76, 1-24.

Zheng, Y.-F. and Hermann, J. (2014) 'Geochemistry of continental subduction-zone fluids', Earth, Planets and Space, 66:93, 16p.

Zheng, Y.-F., Xia, Q.-X., Chen, R.-X. and Gao, X.-Y. (2011) 'Partial melting, fluid supercriticality and element mobility in ultrahigh-pressure metamorphic rocks during continental collision', EarthScience Reviews, 107, 342-374.

Zimmer, M. M., Plank, T., Hauri, E. H., Yogodzinski, g. M., Stelling, P., Larsen, J., Singer, B., Jicha, B., Mandeville, C. and Nye, C. J. (2010) 'The Role of Water in Generating the Calc-Alkaline Trend: New Volatile Data for Aleutian Magmas and a New Tholeiitic Index', Journal of Petrology, 51(12), 2411-2444. 